ARTICLE

\title{
Proxy evidence for state-dependence of climate sensitivity in the Eocene greenhouse
}

\author{
E. Anagnostou (10) ${ }^{1,2}$, E. H. John ${ }^{3}$, T. L. Babila (1) ${ }^{2}$, P. F. Sexton ${ }^{4}$, A. Ridgwell (1) ${ }^{5}$, D. J. Lunt (1) ${ }^{6}$, P. N. Pearson (1) ${ }^{3}$, \\ T. B. Chalk (D) ${ }^{2}$, R. D. Pancost ${ }^{7} \&$ G. L. Foster ${ }^{2}$
}

Despite recent advances, the link between the evolution of atmospheric $\mathrm{CO}_{2}$ and climate during the Eocene greenhouse remains uncertain. In particular, modelling studies suggest that in order to achieve the global warmth that characterised the early Eocene, warmer climates must be more sensitive to $\mathrm{CO}_{2}$ forcing than colder climates. Here, we test this assertion in the geological record by combining a new high-resolution boron isotope-based $\mathrm{CO}_{2}$ record with novel estimates of Global Mean Temperature. We find that Equilibrium Climate Sensitivity (ECS) was indeed higher during the warmest intervals of the Eocene, agreeing well with recent model simulations, and declined through the Eocene as global climate cooled. These observations indicate that the canonical IPCC range of ECS (1.5 to $4.5^{\circ} \mathrm{C}$ per doubling) is unlikely to be appropriate for high- $\mathrm{CO}_{2}$ warm climates of the past, and the state dependency of ECS may play an increasingly important role in determining the state of future climate as the Earth continues to warm.

\footnotetext{
${ }^{1}$ GEOMAR Helmholtz-Zentrum für Ozeanforschung Kiel, Wischhofstrasse 1-3, 24148 Kiel, Germany. ${ }^{2}$ School of Ocean and Earth Science, National Oceanography Centre Southampton, University of Southampton Waterfront Campus, Southampton SO14 3ZH, UK. ${ }^{3}$ School of Earth and Environmental Sciences, Cardiff University, Park Place, Cardiff CF10 3AT, UK. ${ }^{4}$ School of Environment, Earth and Ecosystem Sciences, The Open University, Milton Keynes MK7 6AA, UK. ${ }^{5}$ Department of Earth Sciences, University of California, Riverside, CA 92521, USA. ${ }^{6}$ School of Geographical Sciences, University of Bristol, University Rd, Bristol BS8 1SS, UK. ${ }^{7}$ Organic Geochemistry Unit, School of Chemistry and School of Earth Sciences, Cabot Institute for the Environment, University of Bristol, Queens Rd, Bristol BS8 1UJ, UK. ${ }^{\bowtie}$ email: eanagnostou@geomar.de
} 
T he Eocene Epoch is the most recent greenhouse period in Earth's history. Atmospheric carbon dioxide $\left(\mathrm{CO}_{2}\right)$ and temperature peaked in the early Eocene, and both declined towards the late Eocene, ultimately leading to an icehouse state at the Eocene-Oligocene Transition (e.g. refs. ${ }^{1-5}$ ). However, to better constrain the potential mechanisms driving the early Eocene warmth and the subsequent cooling, high-resolution records of $\mathrm{CO}_{2}$ and temperature are required. While obtaining continuous marine records of temperature through this interval has been an ongoing effort (e.g. refs. ${ }^{1,2}$ ), similar records for $\mathrm{CO}_{2}$, as compiled in ref. ${ }^{3}$, are fragmented and of low temporal resolution with large uncertainties, and thus remain insufficient to fully characterise the climate dynamics of the Eocene.

Of particular importance in this regard are several recent modelling studies that have highlighted the possible existence of a state-dependency of climate sensitivity. That is, the magnitude of global mean temperature change following a doubling of atmospheric $\mathrm{CO}_{2}$ is higher in warm climates than in cooler periods, including the modern climate system (e.g. refs. ${ }^{1,6-8}$ ). In the Eocene, this is thought to result from non-linearities in the albedo response related to cloud feedbacks rather than snow and ice feedbacks ${ }^{6-8}$. These feedbacks are further modified by changing palaeogeography, potentially linked to ocean area and deep water formation ${ }^{8}$. Given the major implications such a state dependency may have on the amount of warming by 2100 and beyond under high-emission scenarios (e.g. RCP8.5), there is a pressing need for improved constraints on the nature and evolution of climate sensitivity in different climate states.

In order to achieve this, we generate a new $\mathrm{CO}_{2}$ record, spanning the Eocene Epoch with an average sampling resolution of 1 sample per 0.25 million years (Myr), using boron isotopes $\left(\delta^{11} \mathrm{~B}\right)$ in planktonic foraminifera from five pelagic sites located in the Atlantic and Pacific: International Ocean Discovery Program (IODP) Sites 1407 and 1409, Newfoundland margin; Ocean Drilling Program (ODP) Sites 1258 and 1260, Demerara Rise, and ODP Site 865, Allison Guyot, (Fig. 1). This record, coupled to existing $\delta^{11} \mathrm{~B}_{-}-\mathrm{CO}_{2}$ reconstructions ${ }^{4,5,9-11}$ and novel Global Mean Temperature (GMT) estimates, is used to provide proxy evidence of the state dependency in climate sensitivity, with higher sensitivity during the warm period of the early Eocene, and lower towards the transition to the colder, late Eocene.

\section{Results and discussion}

Reconstructions of seawater $\mathbf{p H}$. We followed established methods to calculate seawater $\mathrm{pH}$ and $\mathrm{CO}_{2}$ from foraminiferal $\delta^{11} \mathrm{~B}$ measurements ${ }^{4,12-14}$ ("Methods"). We employ the $\delta^{11} \mathrm{~B}$ proxy on mixed-layer species of planktonic foraminifera in all core sites to first reconstruct surface ocean $\mathrm{pH}$. The majority of Paleogene foraminiferal species selected for this study were previously identified to reflect surface mixed layer conditions $s^{4,10}$, and are likely characterized by a reduction in the degree of $\mathrm{pH}$ modification in the micro-environment surrounding the foraminifera by physiological processes compared to observations in modern foraminifera ${ }^{4,14}$. When thermocline dwelling species were used, or additional species not previously analysed, we ensured that our new analyses of $\delta^{11} \mathrm{~B}$ overlapped with previously studied mixed-layer planktonic foraminiferal species ("Methods" and Supplementary Data 1) in order to constrain site-specific intra-species offsets and thus provide consistency and confidence in the derived mixed-layer $\mathrm{pH}$ (as in ref. ${ }^{4}$ ). Seawater temperatures for the calculation of carbonate system parameters from $\delta^{11} \mathrm{~B}$ were estimated using foraminiferal Magnesium/Calcium $(\mathrm{Mg} / \mathrm{Ca})$ ratios determined on an aliquot of the same solution used for $\delta^{11} \mathrm{~B}$ analyses, assuming Eocene seawater $\mathrm{Mg} / \mathrm{Ca}$ of $2.2 \pm$ $0.1 \mathrm{~mol} / \mathrm{mol}^{2,4}$ and the seawater adjusted $\mathrm{Mg} / \mathrm{Ca}$ thermometer ${ }^{15}$.

Reconstructions of atmospheric $\mathrm{CO}_{2}$. The derived surface seawater $\mathrm{pH}$ estimates from foraminiferal $\delta^{11} \mathrm{~B}$ were combined with the latitude-specific estimates of calcite saturation in surface waters (from cGENIE ${ }^{4}$ ), which we assume remains within a range of \pm 1 , thereby accounting for uncertainty in both absolute value and any short-term variability ${ }^{16}$. Full error propagation was carried out using a Monte Carlo approach as described in ref. ${ }^{4}$. The $\mathrm{CO}_{2}$ record was then smoothed using varying span LOESS curve with the degree of smoothing optimised using generalised cross validation (Michael Friendly: https://tolstoy.newcastle.edu. $\mathrm{au} / \mathrm{R} / \mathrm{help} / 05 / 11 / 15899 . \mathrm{html})$. The $95 \%$ confidence intervals were then estimated from smoothing the residuals between the LOESS curve and the $\mathrm{CO}_{2}$ data.

Eocene time-series of $\delta^{11} \mathrm{~B}$-derived $\mathrm{pH}$ and $\mathrm{CO}_{2}$. Our new continuous and high-resolution record of $\delta^{11} \mathrm{~B}$-derived $\mathrm{pH}$ and $\mathrm{CO}_{2}$ (Fig. 2, Supplementary Fig. 1) overlaps with existing lowresolution $\delta^{11} \mathrm{~B}$-based records from Tanzania ${ }^{4,5}$, and records from the Middle Eocene Climatic Optimum (MECO; 40.1-40.5 $\mathrm{Ma})^{11}$, Eocene Thermal Maximum $2(\text { ETM2; } 54.1 \mathrm{Ma})^{9}$, and the Paleocene-Eocene Thermal Maximum (PETM; 56 Ma) ${ }^{9,10}$ (all re-calculated for consistency, see "Methods" and Supplementary Data 3), and demonstrates the validity of our multi-species treatment of $\delta^{11} \mathrm{~B}$ in deriving mixed-layer $\mathrm{pH}$ and $\mathrm{CO}_{2}$ concentrations. This continuous view of the evolution of $\mathrm{CO}_{2}$ confirms that the highest $\mathrm{CO}_{2}$ levels, outside of the short-lived increase in $\mathrm{CO}_{2}$ at the $\mathrm{PETM}^{9,10,17}$, occurred during the Early Eocene Climatic Optimum (EECO; 49-53 Ma ${ }^{18}$ ). Pre-PETM CO

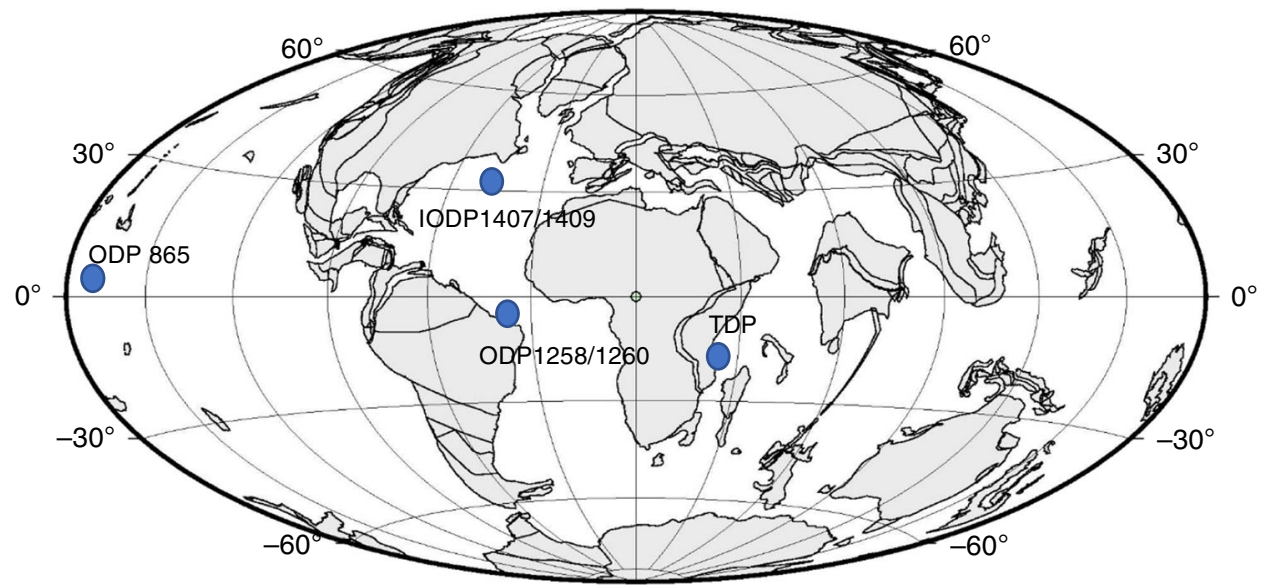

Fig. 1 Paleo-location of sites used in this study. Base map generated from www.odsn.de for the early Eocene. 

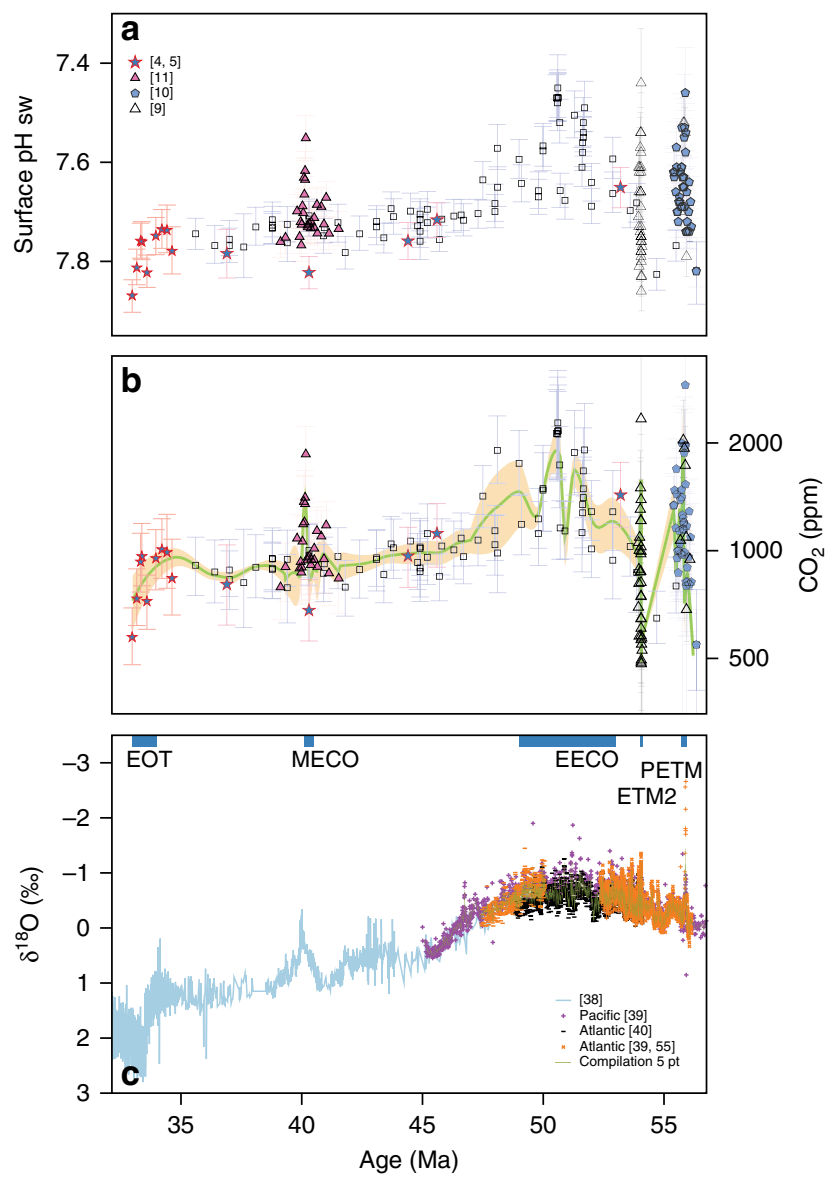

Fig. 2 Compilation of $\boldsymbol{\delta}^{\mathbf{1 1}} \mathrm{B}$ and $\boldsymbol{\delta}^{\mathbf{1 8}} \mathrm{O}$ derived records for the Eocene.

a Seawater $\mathrm{pH}$ from the new $\delta^{11} \mathrm{~B}$ data presented here (black squares) and compiled from the literature (see panel for appropriate references), all listed in Supplementary Data 1 and 3, b calculated atmospheric $\mathrm{CO}_{2}$ from the data shown in $\mathbf{a}$, the LOESS fit (green line) and $95 \%$ confidence (orange shading) (see "Methods" for details), c $\delta^{18} \mathrm{O}$ from benthic foraminifera are based on compilations (see Methods for individual references). Error bars in $\mathbf{a}, \mathbf{b}$ are $95 \%$ confidence. Intervals of time referred to in the text are shown as blue bars in c, labelled with appropriate acronym.

was ca. $900 \pm 100 \mathrm{ppm}( \pm 2 \mathrm{se}, n=14)^{9,10}$. For the EECO and the PETM $^{9,10}$, the average $\mathrm{CO}_{2}$, calculated using the average $\delta^{11} \mathrm{~B}$ and $\mathrm{Mg} / \mathrm{Ca}$-temperature estimates in each interval is $1470(+360 /$ $-300) \mathrm{ppm}(2 \mathrm{s.d}$.) and $1790(+560 /-380) \mathrm{ppm}$ respectively (or $1980(+510 /-440) \mathrm{ppm}$ and $2470(+690 /-540)$ (2 s.d.) if the Trilobatus sacculifer calibration of ref. ${ }^{19}$ is used, as described in the "Methods"). Atmospheric $\mathrm{CO}_{2}$ began to decline from a maximum at ca. $49 \mathrm{Ma}$, reaching a minimum immediately prior to the $\mathrm{MECO}^{4,11}$ where it increased to an average of $1240(+250 /$ $-210) \mathrm{ppm}$ (or $1490(+290 /-240) \mathrm{ppm}$ using the T. sacculifer calibration $)^{18}$. Following the $\mathrm{MECO}, \mathrm{CO}_{2}$ levels remain largely stable at $900 \pm 130 \mathrm{ppm}$ (2 s.d.) until the Eocene-Oligocene transition (EOT; 33.5-34 Ma), when they eventually decline below $700 \mathrm{ppm}^{4,5}$.

Atmospheric $\mathrm{CO}_{2}$, volcanism and silicate weathering. The most important modulators of the Earth's carbon cycle, and hence its climate, are thought to be the balance between volcanic $\mathrm{CO}_{2}$ output and $\mathrm{CO}_{2}$ drawdown through silicate weathering and carbonate burial ${ }^{20}$. However, the relative importance of these processes in determining the evolution of $\mathrm{CO}_{2}$ over the last 65 Myr, and hence their role in the evolution of Cenozoic climate, remains uncertain. Our new continuous $\mathrm{CO}_{2}$ record allows a re-evaluation of the broad relationship between records of silicate weathering, volcanism and $\mathrm{CO}_{2}$ during this interval (Fig. 3).

There is abundant physical evidence for enhanced volcanism during the EECO, potentially driving high levels of $\mathrm{CO}_{2}$ during this time (Fig. 3). The central East Greenland volcanic rift margin plutons associated with post-continental break-up were emplaced from 56 to $54 \mathrm{Ma}$ and 50 to $47 \mathrm{Ma}^{21}$, following the flood basalt of North Atlantic Igneous Province emplacement and volcanism associated with the $\mathrm{PETM}^{22}$. In addition, in central British Columbia there was extensive magmatism within the Chilcotin Plateau (from 55 to $47 \mathrm{Ma}^{23}$ ) and the Challis-Kamloops magmatic belt (from 53 to $47 \mathrm{Ma}^{24,25}$ ). The India-Eurasia collision resulted in the subduction of pelagic carbonates deposited within the Neo-Tethys and of carbonate sediments from the continental margin of the Greater Indian subcontinent, which were most likely recycled as $\mathrm{CO}_{2}$ at arc volcanoes from ca. 52.5 to $49 \mathrm{Ma}^{26}$, also coinciding with the elevated $\mathrm{CO}_{2}$ during the EECO.

The carbon imprint of silicate weathering on the Eocene carbon cycle remains unconstrained (e.g. refs. ${ }^{27,28}$ ) because the available paleoproxies are currently ambiguous and reconstructions tend to be sparse for this time interval ${ }^{29-32}$ (Fig. 3). Only the $\mathrm{Li}$ isotope record ${ }^{33}$ reveals a step change in the early Eocene at ca.48 Ma, indicating that a shift toward higher silicate weathering intensity was coincident with our post-EECO $\mathrm{CO}_{2}$ decline (Fig. 3d). Such an increase in weathering could be due to the second stage of collision of India with Asia 34,35 , and Patagonian orogenesis ${ }^{36}$ that occurred at around 50-49 Ma. Following the EECO warmth and initial cooling, global cooling and reduced weathering intensity, as implied from Os isotopes (Fig. 3b), may have slowed down the weathering feedback ${ }^{27,37}$ contributing to the nearly stable $\mathrm{CO}_{2}$ levels we reconstructed for this time.

Drivers of the ca. $51 \mathrm{Ma}$ decoupling between $\delta^{13} \mathrm{C}$ and $\mathrm{CO}_{2}$. Although the timing of major weathering regime changes and volcanic events coincide with large variations in our $\mathrm{CO}_{2}$ curve, there is structure within our record that require the action of additional processes. Previous work indicates that $\delta^{13} \mathrm{C}$ and $\delta^{18} \mathrm{O}$ values are tightly coupled on short-term orbital scales and across hyperthermals such as the PETM (e.g, ref. ${ }^{38}$ ); however, they decouple on longer timescales, including in the marked transition from ca. 51 to $51.5 \mathrm{Ma}$, characterized by a 1-2 \%o increase in benthic foraminiferal $\delta^{13} \mathrm{C}$ records during the sustained warmth of the EECO (Fig. 3) ${ }^{39,40}$. Our $\mathrm{CO}_{2}$ record demonstrates for the first time that this increase in $\delta^{13} \mathrm{C}$ is not associated with a systematic change in $\mathrm{CO}_{2}$.

Large scale circulation changes could cause this $\delta^{13} \mathrm{C}_{-} \mathrm{CO}_{2}$ decoupling, but they preceded the EECO by ca. $6 \mathrm{My}^{41}$, except the short-lived changes in deep water formation during hyperthermal events, such as the PETM ${ }^{42}$. Additionally, cessation of North Pacific deep-water formation ${ }^{43}$, a more inter-basin thermohaline circulation $\delta^{13} \mathrm{C}$ pattern ${ }^{44}$ (Fig. 3f), and establishment of a protoAntarctic Circumpolar circulation (proto-ACC) associated with the gradual Drake Passage opening (ref. ${ }^{45}$ ) and the Tasman Seaway widening (refs. ${ }^{46,47}$ ) followed the EECO $\mathrm{CO}_{2}$ and temperature decline (post $47 \mathrm{Ma}$ ). Therefore circulation changes are unlikely to have been the main drivers of the $\delta^{13} \mathrm{C}$ and $\mathrm{CO}_{2}$ decoupling within the EECO.

Alternatively, this decoupling could arise from multiple changes in carbon sources and sinks. Volcanic carbon emissions could have been associated with a nearly neutral atmospheric $\delta^{13} \mathrm{C}$ signal while still elevating $\mathrm{CO}_{2}$ concentrations, such as the case of metamorphic degassing of carbonates, whereas the positive $\delta^{13} \mathrm{C}$ excursion can be explained by enhanced burial of $\delta^{13} \mathrm{C}$ depleted organic carbon ${ }^{48}$. Although the amount of organic 


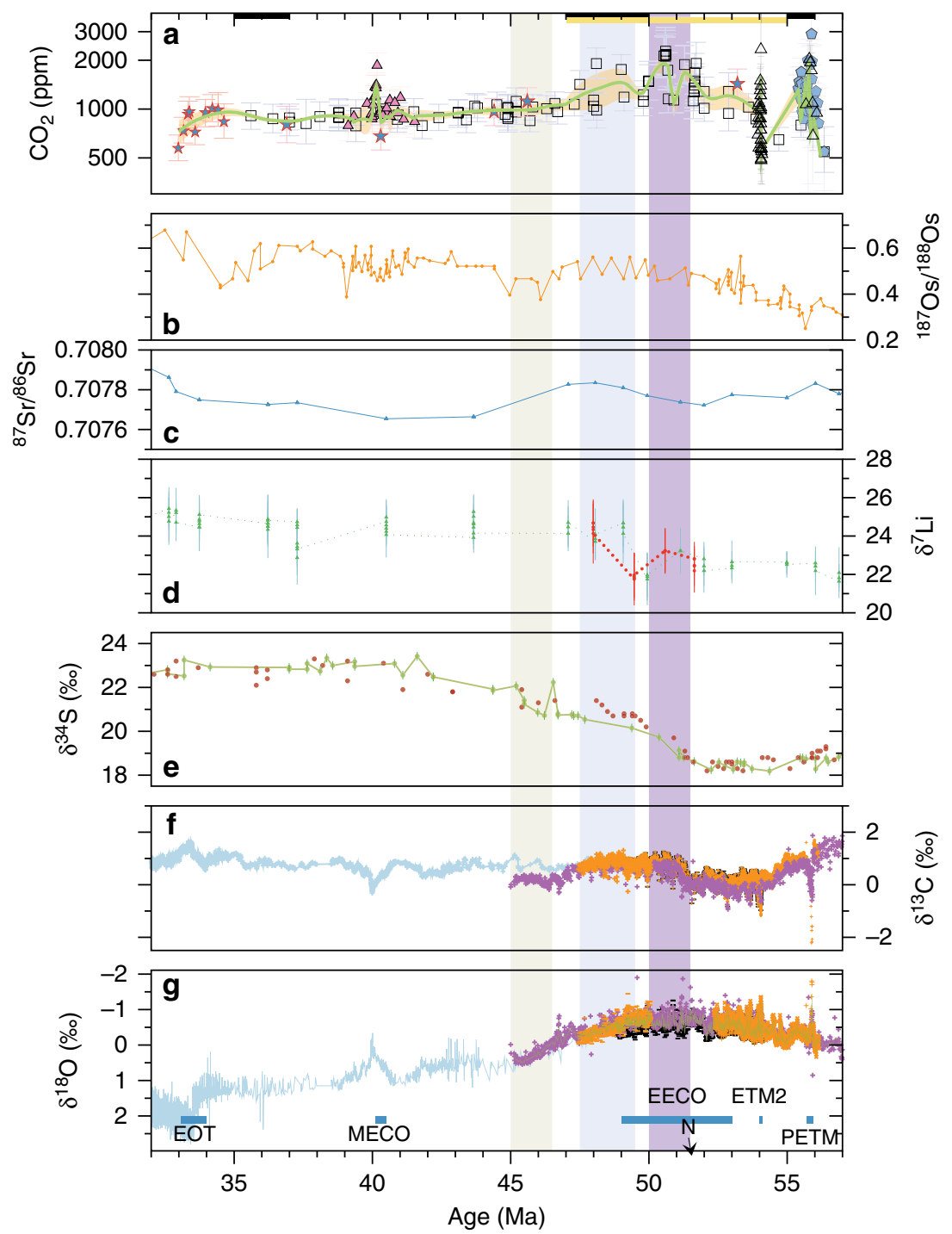

Fig. 3 Early Eocene weathering, organic carbon burial and circulation changes. a The $\mathrm{CO}_{2}$ record as in Fig. 2. b The marine ${ }^{187} \mathrm{Os} /{ }^{188} \mathrm{Os}$ compilation from ref. ${ }^{27} \mathbf{c}$ the marine ${ }^{87} \mathrm{Sr} /{ }^{86} \mathrm{Sr}$ record from refs. ${ }^{30,32,94}$. d The marine $\delta^{7} \mathrm{Li}$ are from ref. ${ }^{33}$, with red symbols/line updated to the same age model as for the $\mathrm{CO}_{2}$ and $\delta^{18} \mathrm{O}$ data ${ }^{39}$. e The marine $\delta^{34} \mathrm{~S}$ are from ref. ${ }^{51}$ (red circles), with the updated age model to GTS2012 (green circles) from ref. ${ }^{53} \mathbf{f}, \mathbf{g}$ Marine carbonate $\delta^{13} \mathrm{C}$ and $\delta^{18} \mathrm{O}$, color coding refers to the same references as in Fig. 2c. Purple bar envelopes the $\delta^{34} \mathrm{~S}$ increase, and " $\mathrm{N}$ " indicates the preceding CIE within $\mathrm{C} 23 \mathrm{n} .2 \mathrm{nH}^{39}$. Light blue bar indicates the timing of temperature and $\mathrm{CO}_{2}$ decline after the EECO. Green light bar indicates the timing of potential circulation changes in the early Eocene, as demonstrated in the $\delta^{13} \mathrm{C}$ record of $\mathbf{f}$. Overlying solid black and yellow bars represent the timing of volcanism ${ }^{21-26}$.

carbon burial across the early Eocene remains debated ${ }^{49,50}$, the most striking evidence for organic carbon burial increase is the $\mathrm{S}$ isotope record obtained from foraminifera calcite ${ }^{51}$ (Fig. 3e) and sedimentary barite ${ }^{52,53}$, which reveals a sharp increase in $\delta^{34} S$ of seawater sulfate starting at ca. $52 \mathrm{Ma}$ and is potentially linked to a change in the locus of organic carbon burial and an increase in the burial of organo-sulfides $51,52,54$.

Global mean temperature and climate sensitivity. Regardless of the causes of the evolution of $\mathrm{CO}_{2}$ through the early Cenozoic, our new $\mathrm{CO}_{2}$ record clearly resembles long-term deep-sea and surface seawater temperature (SST) records as compiled in refs. 1,2,38-40,55, (see "Methods", Fig. 4). To further explore the relationship between $\mathrm{CO}_{2}$ and the global mean temperature evolution during the Eocene, we first computed GMT (Methods). However here, rather than using multi-site, non-continuous foraminiferal $\delta^{18} \mathrm{O}$ records ${ }^{8}$, which have also been shown to be impacted by diagenesis ${ }^{56,57}$, we use the continuous TEX $_{86}$-SST record from the equatorial Atlantic (ODP 959) ${ }^{1}$ and the model simulations with the NCAR Community Earth System Model version 1 (CESM 1) in ref. ${ }^{1}$, which provide a transfer function from SST at ODP 959 to a global mean in four specific time windows (54-49, 48-46, 42-42, 38-35 Ma; Supplementary Fig. 2).

The relative change in climate forcing $\left(\mathrm{W} \mathrm{m}^{-2}\right)$ within the Eocene attributable to $\mathrm{CO}_{2}$ change relative to preindustrial (PI) $\mathrm{CO}_{2}(278 \mathrm{ppm})\left(\Delta \mathrm{FCO}_{2}\right)$ is calculated using the formulation of ref. ${ }^{58}$. Earth System Sensitivity (ESS), defined as the mean temperature response to all radiative perturbations ${ }^{59}$, can then be computed from the change in global mean temperature relative to preindustrial $(\triangle \mathrm{GMT})$, using the equation:

$$
\mathrm{ESS}=\Delta \mathrm{GMT} / \Delta \mathrm{FCO}_{2} \times 3.87
$$

where the $3.87 \mathrm{~W} \mathrm{~m}^{-2}$ expresses the ESS as the temperature change due to a $\mathrm{CO}_{2}$ doubling. However, to isolate the climate change due purely to changes in $\mathrm{CO}_{2}$, we must first account for the influence of paleogeography and solar constant on GMT. To 

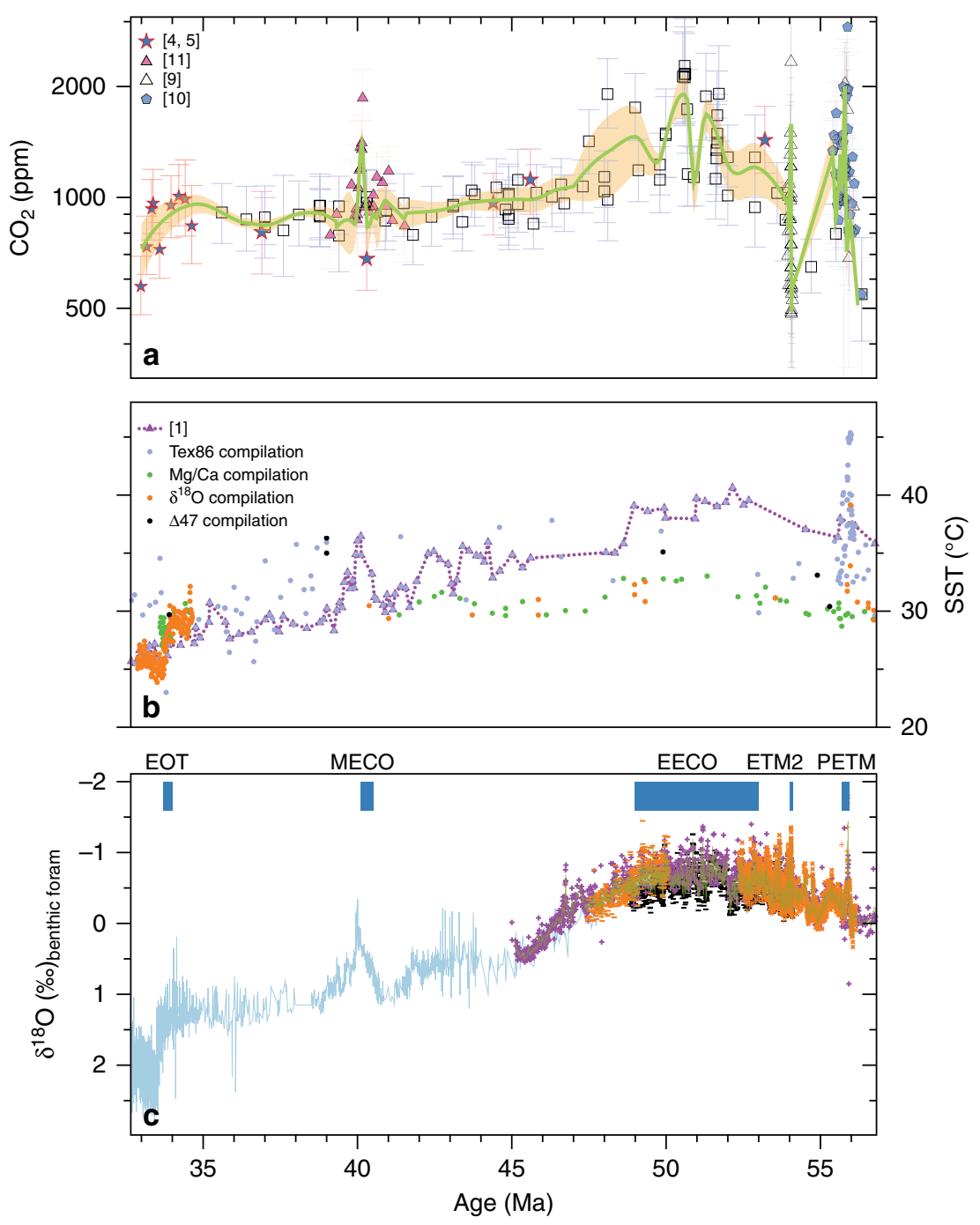

Fig. 4 Comparison of the $\mathbf{\delta}^{\mathbf{1 1}} \mathbf{B}$-derived $\mathbf{C O}_{\mathbf{2}}$ to temperature records. a $\mathrm{CO}_{2}$ compilation as in Fig. $2 \mathrm{a}$, $\mathbf{b}$ Sea surface temperature (SST) records, as compiled in ref. ${ }^{1}$ (see "Methods" for the list of references used in the compilation). Purple dotted line connects the TEX 86 record from ODP 9591. c Benthic foraminifera $\delta^{18} \mathrm{O}$ (related to deep water temperature) as in Fig. 2c.

do this we subtract a time variant correction following ref. ${ }^{8}$ estimated to $\sim 0.5^{\circ} \mathrm{C}$ in the late Eocene and $1.5^{\circ} \mathrm{C}$ in the early Eocene (Supplementary Data 2). Finally, we provide an estimate of Equilibrium Climate Sensitivity (ECS) by accounting for the contribution to Eocene GMT of the changes in the land-ice sheets (equivalent to $1.5 \pm 0.5^{\circ} \mathrm{C}$, refs. ${ }^{60,61}$ ), a slow-climate feedback not considered in climate models (PALAEOSENS ${ }^{59}$ ). To calculate ECS in this way we use Eq. (1), but we first subtract from GMT the estimated temperature changes due to solar constant, paleogeography, and ice sheets (Fig. 5a and Supplementary Data 2). Note that we do not provide any corrections for other greenhouse gasses. Finally, to examine the robustness of our findings to our chosen record of GMT we use an independent alternative approach for calculating GMT from ref. ${ }^{8}$ using foraminiferal $\delta^{18} \mathrm{O}$ (Fig. 5c).

Recently, a number of studies have focused on non-linearities of the climate system during the Eocene, such as those related to changes in paleobathymetry affecting ocean area and deep water formation ${ }^{8}$, and short-wave cloud feedbacks linked to cloud microphysics, amplifying surface warming through changes in clouds $^{6}$. Here we compare our GMT vs. $\triangle \mathrm{FCO}_{2}$ relationship for the Eocene to climate model derived relationships for different boundary condition and processes (Fig. 5b). Largely independent of the approach used for calculating GMT, the majority of our reconstructions fall within the range of Paleogene simulations in refs. ${ }^{6,7}$. Our time-evolving record of ECS (and ESS) through the Eocene, even when considering the large uncertainty it inherits from the individual GMT and $\mathrm{CO}_{2}$ values used for its calculation, shows that the highest ECS estimates occur consistently during the warm intervals of the Eocene, such as the PETM, ETM2, EECO and MECO, and progressively decline towards the EOT (Fig. 5a).

The declining ECS for the Eocene, and the overlap between our early Eocene climate sensitivity estimates and the model output of ref. ${ }^{6}$ (Fig. 5b), provide a strong confirmation of state dependency of ECS likely driven by changes in cloud-microphysics ${ }^{6}$. This finding is robust to the uncertainties in final estimates of ECS as it is present in all processing scenarios we consider which largely influence our estimates of absolute ECS, not the pattern of its evolution through time. The decrease in GMT that we observe post $39 \mathrm{Ma}$ (Fig. 5b), however, is not sufficiently described by this early Eocene model, implying that non- $\mathrm{CO}_{2}$ boundary conditions may be playing a role in changing climate at this time, such as changes in paleogeography and/or associated changes in ocean circulation, and the presence of ice sheets ${ }^{8,47,62-65}$.

Our new compilation of $\delta^{11} \mathrm{~B}-\mathrm{CO}_{2}$ from planktonic foraminifera from multiple open ocean sites provides a comprehensive 

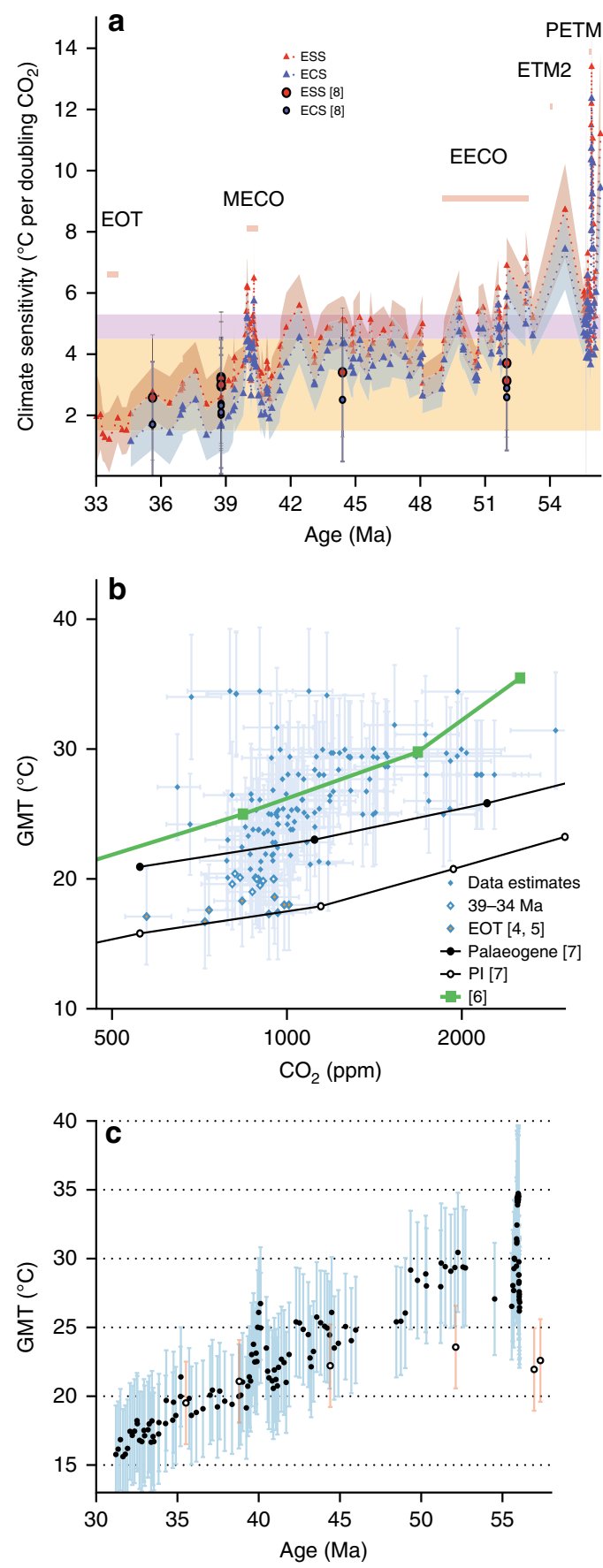

Fig. 5 Evolving climate sensitivity for the Eocene. a Calculated ESS (red triangles and error envelope), and ECS (blue triangles and error envelope). See text for relevant methodology. Orange area represents the IPCC range in $\mathrm{ECS}^{95}$, and the pink highlighted area the updated 20th century ECS with the addition of state-of-the-art cloud physics ${ }^{96}$. Circles represent estimates from ref. ${ }^{8}$. b Data-model inter-comparison, with all diamonds representing data. Open diamonds are the data between 39 and $34 \mathrm{Ma}$, and orange filled diamonds the EOT. Circles ${ }^{7}$ and squares ${ }^{6}$ are all model derived relationships (PI preindustrial). Uncertainties and error envelopes represent 1 s.d. of Monte Carlo propagated uncertainties. c Evolving GMT relationship for the Eocene. GMT is calculated using the BAYSPAR TEX ${ }_{86}$ record from ODP 959. Error bars represent the calibration and analytical uncertainty on TEX $_{86}$. For comparison, the GMT estimates from ref. ${ }^{8}$ are presented with open symbols and red error bars. NB the elevated ECS early in the PETM and ETM 2 are most likely a consequence of slight age model misalignments, or imply non- $\mathrm{CO}_{2}$ forcing early in these events. picture of the evolution of $\mathrm{CO}_{2}$ through the Eocene, greatly improving on recent $\mathrm{CO}_{2}$ compilations (ref. ${ }^{3}$ and Supplementary Fig. 3) and allowing for the first direct comparison with highresolution records of climate variability. Our reconstructions, while still underlining the importance of $\mathrm{CO}_{2}$ in driving the evolution of Eocene climate, provide evidence of strong nonlinearities between climate and $\mathrm{CO}_{2}$ forcing, likely related to both cloud feedbacks for the early-mid Eocene, and changing paleogeography and ice sheets for the late Eocene. This reveals climate-state dependent feedbacks and elevated ECS operated during the warmest climates of the last 65 million years.

\section{Methods}

Site information and age models. Boron isotopes $\left(\delta^{11} \mathrm{~B}\right)$ from mono-specific samples of planktonic foraminifera were obtained from a number of deep-sea, open-ocean Paleogene-age core locations (Fig. 1). Sites ODP 865 and ODP 1258 and 1260 were positioned in subtropical/tropical paleolatitude and Sites IODP 1407/1409 was likely within temperate latitudes (Fig. 1), and all sites were located within deep-bathyal water depths throughout the Eocene above the calcite compensation depth (CCD) ${ }^{44,66-68}$. Age models for IODP 1407/1409 and ODP 1258/60 were updated to ref. ${ }^{39}$ timescale.

The age-depth model used for site 865B (Supplementary Table 1 and Supplementary Fig. 4) in this study was based on that from ref. ${ }^{69}$, with refinements in this study including re-adjustment to the GTS2012 $2^{70}$ timescale. The model uses a linear $\mathrm{fit}^{71}$, but it is solely based on planktonic foraminiferal events (excluding nannofossils), because of suspected winnowing bottom water currents that may have mobilized the fine fraction containing nannofosils, making them suspect. We only used datums for which GTS2012 ages were available and in which we had significant confidence (Supplementary Table 1), such as those without obvious signs of reworking.

At Sites IODP 1407 and 1409 the planktonic foraminifera exhibit glassy test textures and appear minimally influenced by post-depositional recrystallization ${ }^{68}$, while at ODP 1258/1260 and ODP 865 the foraminifera specimens are frosty in appearance ${ }^{57,72}$, indicative of partial or complete recrystallization, with the most altered site being ODP 865 , without hampering identification of individual species. Nevertheless, it has been shown that at least at ca. $40.3 \mathrm{Ma}$, ODP $865 \delta^{11} \mathrm{~B}$ of planktonic and benthic foraminifera are indistinguishable from that of glassy, wellpreserved foraminifera from the Tanzania Drilling Project (TDP) ${ }^{73}$.

Records of $\delta^{13} \mathrm{C}$ and $\delta^{18} \mathrm{O}$ displayed in Fig. 2 to Fig. 4 were generated from ODP Sites 1258 ,

1262, 1263, 1265 and 1267 and 1209 in refs. ${ }^{40,55,74-81}$, on the ref. ${ }^{39}$ age model, and from Deep Sea Drilling Project and ODP sites in ref. ${ }^{38}$.

Sample preparation. Approximately $3 \mathrm{mg}$ of 73 mono-specific planktonic foraminiferal carbonate samples of a narrow size fraction (Supplementary Data 1) were separated from 2 to $10 \mathrm{~cm}$ of core material for tandem analyses of boron isotopes and trace element composition. Identification of planktonic foraminifera followed ref. ${ }^{57}$, and samples were cleaned following established methods ${ }^{82-84}$. Trace element to calcium ratios were determined as in ref. ${ }^{84}$ and $\mathrm{Al} / \mathrm{Ca}$ ratios were typically $<150 \mu \mathrm{mol} / \mathrm{mol}$ signifying efficient surficial clay removal during the foraminiferal cleaning procedure ${ }^{84}$. For all core sites used in this study, there was no relationship between $\mathrm{Al} / \mathrm{Ca} \mu \mathrm{mol} / \mathrm{mol}$ and foraminiferal $\delta^{11} \mathrm{~B}$ measurements, suggesting that any clay remnants did not bias the measured $\delta^{11} \mathrm{~B}$ values ${ }^{10}$.

$\mathrm{Mg} / \mathrm{Ca}$ analyses, temperature reconstructions. Trace element to calcium analyses were carried out using a Thermo Scientific Element XR sector-field inductively-coupled-plasma mass spectrometer (SF-ICPMS) at the University of Southampton. The long-term precision (2 s.d.) of an in-house carbonate standard was $2 \%$ for $\mathrm{Mg} / \mathrm{Ca}(\mathrm{mmol} / \mathrm{mol})$ and $\mathrm{Al} / \mathrm{Ca}(\mu \mathrm{mol} / \mathrm{mol})$. Seawater temperature was estimated from each sample using foraminiferal $\mathrm{Mg} / \mathrm{Ca}$ ratio on an aliquot of the same solution used for $\delta^{11} \mathrm{~B}$ analyses, assuming Eocene seawater $\mathrm{Mg} / \mathrm{Ca}$ of $2.2 \pm 0.1 \mathrm{~mol} / \mathrm{mol}^{2,4}$ and $\mathrm{Mg} / \mathrm{Ca}$-temperature calibration sensitivity was adjusted based on the seawater $\mathrm{Mg} / \mathrm{Ca}$ value ${ }^{15}$. The temperature uncertainty is set to a range of $\pm 2{ }^{\circ} \mathrm{C}$ and it is fully propagated into our carbonate system estimates (see below).

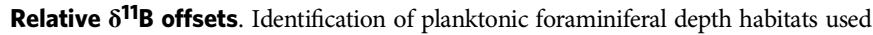
in this study are based on relationships between stable isotope foraminiferal geochemistry and ecology in relationship to $\delta^{11} \mathrm{~B}$ offsets (e.g., refs. ${ }^{4,9,10}$, and references therein). Additional foraminifera species used here (Morozovella aragonensis, Acarinina quetra, A. pentacamerata, M. crater, A. cuneicamerata, A. pseudosubsphaerica) were cross-calibrated against previously known species (A. pseudotopilensis, $A$. praetopilensis, A. soldadoensis, Guembelitrioides nuttalli, Pearsonites broedermanni) for their $\delta^{11} \mathrm{~B}$ behaviour collected from the same time interval and core site $\mathrm{e}^{4,5,11,17}$ and site-specific species offsets in $\delta^{11} \mathrm{~B}$ were not identified. In site ODP 865 , the $\delta^{11} \mathrm{~B}$ composition of Turborotalia cerroazulensis, T. frontosa, and T. ampliapertura are offset from the mixed layer species A. rohri, A. praetopilensis and A. topilensis by on 
average $1.02 \pm 0.04$ ( 2 s.e., $n=3$ ) \%o, confirming previous estimates for T. ampliapertura ${ }^{4}$, but showing less of an offset for the species T. cerroazulensis compared to $\mathrm{TDP}^{4}$, thus we used the site-specific offset here for this species, propagating the uncertainty of this offset correction through the calculations. Sites 1407 and 1409 are dominated by A. bullbrooki in the late Eocene which recorded variably lower $\delta^{11} \mathrm{~B}$ values than known shallow mixed layer species and so were excluded from the time series compilation. For consistency, we have included previously published $\delta^{11} \mathrm{~B}$ records generated from planktonic foraminiferal species we have tested for relative vital effects and interspecies offsets in our timeseries. Therefore, we excluded the M. velascoensis record of the PETM $^{17}$, since this species is randomly offset from our tested species A. soldadoensis when comparing five samples from site 1209 and at

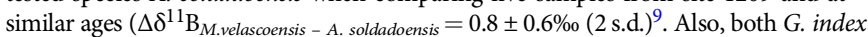
and G. kugleri records of the $\mathrm{MECO}^{11}$ are excluded, because the former showed variable habitat depth and $\delta^{11} \mathrm{~B}$ offsets in $\mathrm{TDP}^{4}$, and the latter is not sufficiently tested for within site inter species offsets.

Boron isotope proxy and analyses. Boron isotopes in planktonic foraminifera have been used extensively to reconstruct past ocean $\mathrm{pH}$ and thus $\mathrm{CO}_{2}$ concentrations e.g., refs. 4,10,84,85. Here we use the Thermo Scientific Neptune multicollector ICP-MS at the University of Southampton. External reproducibility of $\delta^{11} \mathrm{~B}$ analyses is calculated from the long-term precision of consistency standards, and two relationships depending on the amplifiers used for the Faraday cups;

For $10^{12}$ amplifiers : $129600 * e^{\left(-212^{* 11} B(\text { Volts })\right)}+0.339 * e^{\left(-1.544^{* 11} B(\text { Volts })\right)}$

For $10^{11}$ amplifiers : $2.251 * e^{\left(-23.01^{* 11} B(\text { Volts })\right)}+0.278 * e^{\left(-0.639^{* 11} B(\text { Volts })\right)}$

The seawater boron isotopic composition $\left(\delta^{11} \mathrm{~B}_{\mathrm{sw}}\right)$ for the Eocene has been estimated in ref. ${ }^{4}$ based on two scenarios, one involving no vital-effect corrections $(38.2-38.7 \%)$ and one using the modern surface dwelling Trilobatus sacculifer ${ }^{19}$ $\delta^{11} \mathrm{~B}$ calibration (38.6-38.9\%o).

For the targeted Eocene planktonic foraminiferal species, $\delta^{11} \mathrm{~B}$ vital effects as observed in modern (extant) species are likely not applicable ${ }^{4}$. If vital effects are present in Eocene foraminiferal $\delta^{11} \mathrm{~B}$, these only played a minor role ${ }^{4,17}$, supported by the demonstration that during periods of reduced $\delta^{11} \mathrm{~B}_{\mathrm{sw}}$, vital effect corrections on $\delta^{11} \mathrm{~B}$ are also reduced ${ }^{14}$, especially for when targeting small size fraction foraminifera as in this study (Supplementary Data 1). Nonetheless, we also apply the modern T. sacculifer calibration ${ }^{19}$ (for the 300 to $355 \mu \mathrm{m}$ size fraction), adjusting the intercept of the calibration to Eocene-specific $\delta^{11} \mathrm{~B}_{\mathrm{sw}}$ as described in ref. ${ }^{14}$ (T. sacculifer $\delta^{11} \mathrm{~B}-\mathrm{pH}$ proxy intercept $=1.748$ for average $\delta^{11} \mathrm{~B}_{\mathrm{sw}}=$ $38.75 \%$ ).

This provides an upper limit on potential $\delta^{11} \mathrm{~B}$ vital effects in the Eocene planktonic foraminifera selected here. Notably, our calculated $\mathrm{pH}$ and $\mathrm{CO}_{2}$ estimates for both approaches are largely within uncertainty (Supplementary Data 1).

Second carbonate parameter. After computing seawater pH using Eocene $\delta^{11} \mathrm{~B}_{\mathrm{sw}}$ and foraminiferal $\delta^{11} \mathrm{~B}$, an additional carbonate parameter is required to calculate $\mathrm{CO}_{2}$ concentrations at any given seawater salinity and temperature. Here, the second parameter we use is the surface oceanic saturation of calcite (surface $\left.\Omega_{\text {calc }}=[\mathrm{Ca}]_{\mathrm{sw}} *\left[\mathrm{CO}_{3}{ }^{2-}\right] / \mathrm{K}_{\mathrm{sp}}\right)$, estimated at different paleolatitudes ${ }^{4}$. For IODP $1407 / 1409, \Omega_{\text {calc }}$ is estimated at $4.5 \pm 1$, for ODP 865 and ODP $1258 / 1260 \Omega_{\text {calc }}$ is estimated at $6.5 \pm 1$, for the re-processing of the $\delta^{11} \mathrm{~B}$ data of ${ }^{10}$ from DSDP 401 we used $\Omega_{\text {calc }}=5.5 \pm 1$, and for the data from ODP1209/1210 and ODP 1265 in ref. ${ }^{9}$ we used $\Omega_{\text {calc }}=6$ and $4.5( \pm 1)$, respectively. In support of the narrow range of potential $\Omega_{\text {calc }}$, a variety of carbon cycle modelling studies of the early Cenozoic oceans show that surface water $\Omega_{\text {calc }}$ remains, within \pm 1 , essentially constant and independent of model boundary conditions ${ }^{16,85,86}$.

Monte Carlo $\mathrm{pH}-\mathrm{CO}_{2}$ estimates from planktonic foraminiferal $\boldsymbol{\delta}^{11} \mathrm{~B}$. We followed established methods to calculate seawater $\mathrm{pH}$ and $\mathrm{CO}_{2}$ from foraminiferal $\delta^{11} \mathrm{~B}^{12-14}$. Atmospheric $\mathrm{CO}_{2}$ was calculated using a Monte Carlo approach to solve the relevant carbonate system equations with 1000 iterations, deriving mean, upper and lower bounds of $95 \%$ of the simulations. We use the seawater $\mathrm{Ca}$ and $\mathrm{Mg}$ concentrations and salinity constraints in ref. ${ }^{4}$ and the equation in ref. ${ }^{12,13}$ to correct for ion pairing. For each $\mathrm{CO}_{2}$ estimate, the $\mathrm{Mg} / \mathrm{Ca}$ derived temperature from the same aliquot was used, with a $\pm 2{ }^{\circ} \mathrm{C}$ uncertainty. All simulations were iterative assuming Gaussian distribution of these parameters within the stated 2 sigma error envelope of the mean. Note that a Gaussian distribution is not applicable to $\delta^{11} \mathrm{~B}_{\mathrm{sw}}$ because there is equal likelihood that it lay between the minimum and maximum constraints; we therefore applied a uniform probability $\delta^{11} \mathrm{~B}_{\mathrm{sw}}$ for the Monte Carlo simulations.

GMT calculations. We convert the ODP 959 TEX $_{86}$ SST record of ref. ${ }^{1}$ to GMT, employing previously published model simulations with the NCAR CESM version 1 with CAM $4^{1}$, which essentially provides a transfer function from SST at ODP 959 to a global mean in four specific time windows (54-49, 48-46, 42-42, 38-35 Ma; Supplementary Fig. 2). The regression is then:

$$
\mathrm{GMT}=0.91( \pm 0.04) \times \mathrm{SST}\left(\mathrm{ODP} 959, \mathrm{TEX}_{86}\right)-6.66( \pm 1.3)(1 \text { s.d. })
$$

Previous model simulations of ocean temperature are consistent with both proxy estimations of SST and deep-sea temperatures at multiple locations ${ }^{1}$. It is important to note that the calculation does not depend on the climate sensitivity of the model, just the relationship between local and global temperature. The resulting relationship between GMT and SST from ODP 959 is then interpolated for the remaining part of the $\mathrm{TEX}_{86}$ record in ref. ${ }^{1}$, resulting in a time-resolved GMT record for the Eocene (Fig. 5c). A similar GMT record is generated when the same approach is applied to the tropical SST compilation ${ }^{1,2,57,65,87-93}$ summarized in ref. ${ }^{1}$ and Fig. 4, albeit with greater noise possibly the result of inconsistencies in tuning the transfer function for multiple sites and for different time intervals of the curve (Supplementary Figs. 2 and 5). The agreement between GMT records estimated from ODP 959 compared to the tropical-multi site compilation confirms that this approach is not dependent on the regional temperature, as long as the tie points are able to capture the major variations in each time series. The relevant uncertainty for each estimate of GMT (Fig. 5 and Supplementary Data 2) is the product of 1000 realization of $\mathrm{TEX}_{86}$-temperature reconstruction and analytical uncertainty ${ }^{1}$, randomly sampled within its $95 \%$ CI uncertainty envelope, including the standard errors of the regression (Supplementary Fig. 2).

\section{Data availability}

The authors declare that all data supporting the findings of this study are available within the Supplementary Information and Supplementary Data files associated with this paper.

Received: 29 December 2019; Accepted: 22 July 2020;

Published online: 07 September 2020

\section{References}

1. Cramwinckel, M. J. et al. Synchronous tropical and polar temperature evolution in the Eocene. Nature 559, 382-386 (2018).

2. Evans, D. et al. Eocene greenhouse climate revealed by coupled clumped isotope-Mg/Ca thermometry. Proc. Natl Acad. Sci. USA 115, 1174 (2018).

3. Foster, G. L., Royer, D. L. \& Lunt, D. J. Future climate forcing potentially without precedent in the last 420 million years. Nat. Commun. 8, 14845 (2017).

4. Anagnostou, E. et al. Changing atmospheric $\mathrm{CO}_{2}$ concentration was the primary driver of early Cenozoic climate. Nature 533, 380-384 (2016).

5. Pearson, P. N., Foster, G. L. \& Wade, B. S. Atmospheric carbon dioxide through the Eocene-Oligocene climate transition. Nature 461, 1110-1113 (2009).

6. Zhu, J., Poulsen, C. J. \& Tierney, J. E. Simulation of Eocene extreme warmth and high climate sensitivity through cloud feedbacks. Sci. Adv. 5, eaax1874 (2019).

7. Caballero, R. \& Huber, M. State-dependent climate sensitivity in past warm climates and its implications for future climate projections. Proc. Natl Acad. Sci. USA 110, 14162-14167 (2013).

8. Farnsworth, A. et al. Climate sensitivity on geological timescales controlled by nonlinear feedbacks and ocean circulation. Geophys. Res. Lett. 46, 9880-9889 (2019).

9. Harper, D. T. et al. The magnitude of surface ocean acidification and carbon release during Eocene Thermal Maximum 2 (ETM-2) and the Paleocene-Eocene Thermal Maximum (PETM). Paleoceanogr. Paleoclimatol 35, e2019PA003699 (2020).

10. Gutjahr, M. et al. Very large release of mostly volcanic carbon during the Paleocene-Eocene Thermal Maximum Paleocene-Eocene Thermal Maximum. Nature 548, 573-577 (2017)

11. Henehan, M. J. et al. Revisiting the Middle Eocene Climatic Optimum 'Carbon Cycle Conundrum' with new estimates of atmospheric $\mathrm{pCO}_{2}$ from boron isotopes. Paleoceanogr. Paleoclimatol 35, e2019PA003713 (2020).

12. Hain, M. P., Sigman, D. M., Higgins, J. A. \& Haug, G. H. The effects of secular calcium and magnesium concentration changes on the thermodynamics of seawater acid/base chemistry: Implications for Eocene and Cretaceous ocean carbon chemistry and buffering. Glob. Biogeochem. Cycles 29, 2014GB004986 (2015).

13. Hain, M. P., Sigman, D. M., Higgins, J. A. \& Haug, G. H. Response to comment by Zeebe and Tyrrell on "The effects of secular calcium and magnesium concentration changes on the thermodynamics of seawater acid/base chemistry: Implications for the Eocene and Cretaceous ocean carbon chemistry and buffering". Glob. Biogeochem. Cy 32, 898-901 (2018).

14. Greenop, R. et al. Orbital forcing, ice volume, and $\mathrm{CO}_{2}$ across the OligoceneMiocene transition. Paleoceanogr. Paleoclimatol 34, 316-328 (2019).

15. Evans, D., Brierley, C., Raymo, M. E., Erez, J. \& Müller, W. Planktic foraminifera shell chemistry response to seawater chemistry: Pliocene-Pleistocene seawater $\mathrm{Mg} / \mathrm{Ca}$, temperature and sea level change. Earth Planet. Sci. Lett. 438, 139-148 (2016) 
16. Zeebe, R. E. \& Tyrrell, T. History of carbonate ion concentration over the last 100 million years II: Revised calculations and new data. Geochim. Cosmochim. Acta 257, 373-392 (2019).

17. Penman, D. E., Hönisch, B., Zeebe, R. E., Thomas, E. \& Zachos, J. C. Rapid and sustained surface ocean acidification during the Paleocene-Eocene Thermal Maximum. Paleoceanography 29, 2014 PA002621 (2014).

18. Hollis, C. J. et al. The DeepMIP contribution to PMIP4: methodologies for selection, compilation and analysis of latest Paleocene and early Eocene climate proxy data, incorporating version 0.1 of the DeepMIP database. Geosci. Model Dev. 12, 3149-3206 (2019).

19. Foster, G. L., Lear, C. H. \& Rae, J. W. B. The evolution of $\mathrm{pCO}_{2}$, ice volume and climate during the middle Miocene. Earth Plan. Sci. Lett. 341-344, 243-254 (2012).

20. Berner, R. A., Lasaga, A. C. \& Garrels, R. M. The carbonate-silicate geochemical cycle and its effect on atmospheric carbon dioxide over the past 100 million years. Am. J. Sci. 283, 641-683 (1983).

21. Tegner, C., Brooks, C. K., Duncan, R. A., Heister, L. E. \& Bernstein, S. 40Ar-39Ar ages of intrusions in East Greenland: Rift-to-drift transition over the Iceland hotspot. Lithos 101, 480-500 (2008).

22. Storey, M., Duncan, R. A. \& Swisher, C. C. Paleocene-Eocene thermal maximum and the opening of the Northeast Atlantic. Science 316, 587-589 (2007).

23. Bordet, E. et al. Chronostratigraphy of Eocene volcanism, central British Columbia. Can. J. Earth Sci. 51, 56-103 (2013).

24. Ickert, R. B., Thorkelson, D. J., Marshall, D. D. \& Ullrich, T. D. Eocene adakitic volcanism in southern British Columbia: remelting of arc basalt above a slab window. Tectonophysics 464, 164-185 (2009).

25. Dostal, J., Church, B. N., Reynolds, P. H. \& Hopkinson, L. Eocene volcanism in the Buck Creek Basin, Central British Columbia (Canada): Transition from arc to extensional volcanism. J. Volcanol. Geotherm. Res. 107, 149-170 (2001).

26. Hoareau, G. et al. Did high Neo-Tethys subduction rates contribute to early Cenozoic warming? Clim 11, 1751-1767 (2015).

27. van der Ploeg, R. et al. Middle Eocene greenhouse warming facilitated by diminished weathering feedback. Nat. Commun. 9, 2877 (2018).

28. Li, G. \& Elderfield, H. Evolution of carbon cycle over the past 100 million years. Geochim. Cosmochim. Acta 103, 11-25 (2013).

29. Oliver, L. et al. Silicate weathering rates decoupled from the ${ }^{87} \mathrm{Sr} /{ }^{86} \mathrm{Sr}$ ratio of the dissolved load during Himalayan erosion. Chem. Geol. 201, 119-139 (2003).

30. Hodell, D. A. et al. Variations in the strontium isotope composition of seawater during the Paleocene and early Eocene from ODP Leg 208 (Walvis Ridge). Geochem. Geophys. Geosys. 8, Q09001 (2007)

31. Peucker-Ehrenbrink, B. \& Ravizza, G. The marine osmium isotope record. Terra Nova 12, 205-219 (2000).

32. McArthur, J. M., Howarth, R. J. \& Bailey, T. R. Strontium isotope stratigraphy: LOWESS Version 3: Best fit to the marine Sr-isotope curve for 0-509 Ma and accompanying look-up table for deriving numerical age. J. Geol. 109, 155-170 (2001).

33. Misra, S. \& Froelich, P. N. Lithium isotope history of Cenozoic seawater: changes in silicate weathering and reverse weathering. Science 335, 818-823 (2012).

34. Müller, R. D. et al. A global plate model including lithospheric deformation along major rifts and orogens since the Triassic. Tectonics 38, 1884-1907 (2019).

35. Zahirovic, S. et al. Tectonic evolution and deep mantle structure of the eastern Tethys since the latest Jurassic. Earth-Sci. Rev. 162, 293-337 (2016)

36. Maffione, M., Speranza, F., Faccenna, C. \& Rossello, E. Paleomagnetic evidence for a pre-early Eocene ( $50 \mathrm{Ma})$ bending of the Patagonian orocline (Tierra del Fuego, Argentina): Paleogeographic and tectonic implications. Earth Planet. Sci. Lett. 289, 273-286 (2010).

37. Fang, X. et al. Paleogene global cooling-induced temperature feedback on chemical weathering, as recorded in the northern Tibetan Plateau. Geology 47, 992-996 (2019).

38. Zachos, J. C., Dickens, G. R. \& Zeebe, R. E. An early Cenozoic perspective on greenhouse warming and carbon-cycle dynamics. Nature 451, 279-283 (2008).

39. Westerhold, T. et al. Astronomical calibration of the Ypresian timescale: implications for seafloor spreading rates and the chaotic behavior of the solar system? Clim 13, 1129-1152 (2017).

40. Lauretano, V., Zachos, J. C. \& Lourens, L. J. Orbitally paced carbon and deepsea temperature changes at the peak of the Early Eocene Climatic Optimum. Paleoceanogr. Paleoclimatol 33, 1050-1065 (2018).

41. Batenburg, S. J. et al. Major intensification of Atlantic overturning circulation at the onset of Paleogene greenhouse warmth. Nat. Commun. 9, 4954 (2018).

42. Nunes, F. \& Norris, R. D. Abrupt reversal in ocean overturning during the Palaeocene/Eocene warm period. Nature 439, 60-63 (2006).

43. Thomas, D. J. Evidence for deep-water production in the North Pacific Ocean during the early Cenozoic warm interval. Nature 430, 65-68 (2004).
44. Sexton, P. F., Wilson, P. A. \& Norris, R. D. Testing the Cenozoic multisite composite $\delta^{18} \mathrm{O}$ and $\delta^{13} \mathrm{C}$ curves: new monospecific Eocene records from a single locality, Demerara Rise (Ocean Drilling Program Leg 207). Paleoceanography 21, PA2019 (2006).

45. Scher, H. D. \& Martin, E. E. Timing and climatic consequences of the opening of Drake Passage. Science 312, 428-430 (2006).

46. van de Flierdt, T. et al. Deep and bottom water export from the Southern Ocean to the Pacific over the past 38 million years. Paleoceanography 19, PA1020 (2004).

47. Huck, C. E., van de Flierdt, T., Bohaty, S. M. \& Hammond, S. J. Antarctic climate, Southern Ocean circulation patterns, and deep water formation during the Eocene. Paleoceanography 32, 674-691 (2017).

48. Mason, E., Edmonds, M. \& Turchyn, A. V. Remobilization of crustal carbon may dominate volcanic arc emissions. Science 357, 290-294 (2017).

49. Lyle, O. A. \& Lyle, M. W. Missing organic carbon in Eocene marine sediments: Is metabolism the biological feedback that maintains end-member climates? Paleoceanography 21, PA2007 (2006).

50. Faul, K. L. \& Delaney, M. L. A comparison of early Paleogene export productivity and organic carbon burial flux for Maud Rise, Weddell Sea, and Kerguelen Plateau, south Indian Ocean. Paleoceanography 25, PA3214 (2010).

51. Rennie, V. C. F. et al. Cenozoic record of $\delta^{34} \mathrm{~S}$ in foraminiferal calcite implies an early Eocene shift to deep-ocean sulfide burial. Nat. Geosci. 11, 761-765 (2018).

52. Paytan, A., Kastner, M., Campbell, D. \& Thiemens, M. H. Sulfur isotopic composition of Cenozoic seawater sulfate. Science 282, 1459-1462 (1998).

53. Yao, W. et al. A revised seawater sulfate S-isotope curve for the Eocene. Chem Geol. 532, 119382 (2020).

54. Kurtz, A. C., Kump, L. R., Arthur, M. A., Zachos, J. C. \& Paytan, A. Early Cenozoic decoupling of the global carbon and sulfur cycles. Paleoceanography 18, 1090 (2003).

55. Westerhold, T., Röhl, U., Donner, B. \& Zachos, J. C. Global extent of early Eocene hyperthermal events: a new Pacific benthic foraminiferal isotope record from Shatsky Rise (ODP Site 1209). Paleoceanogr. Paleoclimatol 33 626-642 (2018).

56. Kozdon, R. et al. In situ $\delta^{18} \mathrm{O}$ and $\mathrm{Mg} / \mathrm{Ca}$ analyses of diagenetic and planktic foraminiferal calcite preserved in a deep-sea record of the Paleocene-Eocene thermal maximum. Paleoceanography 28, 517-528 (2013).

57. Pearson, P. N. et al. Stable warm tropical climate through the Eocene Epoch Geology 35, 211-214 (2007).

58. Byrne, B. \& Goldblatt, C. Radiative forcing at high concentrations of wellmixed greenhouse gases. Geophys. Res. Lett. 41, 152-160 (2014).

59. PALAEOSENS. Making sense of palaeoclimate sensitivity. Nature 491 , 683-691 (2012)

60. Kennedy, A. T., Farnsworth, A., Lunt, D. J., Lear, C. H. \& Markwick, P. J. Atmospheric and oceanic impacts of Antarctic glaciation across the Eocene Oligocene transition. Philos. Trans. R. Soc. A 373, 20140419 (2015).

61. Goldner, A., Herold, N. \& Huber, M. Antarctic glaciation caused ocean circulation changes at the Eocene-Oligocene transition. Nature 511, 574-577 (2014).

62. Sijp, W. P., England, M. H. \& Huber, M. Effect of the deepening of the Tasman Gateway on the global ocean. Paleoceanography 26, PA4207 (2011).

63. Coxall, H. K. et al. Export of nutrient rich Northern Component Water preceded early Oligocene Antarctic glaciation. Nat. Geosci. 11, 190-196 (2018).

64. Scher, H. D., Bohaty, S. M., Smith, B. W. \& Munn, G. H. Isotopic interrogation of a suspected late Eocene glaciation. Paleoceanography 29, 2014PA002648 (2014)

65. Lear, C. H., Bailey, T. R., Pearson, P. N., Coxall, H. K. \& Rosenthal, Y. Cooling and ice growth across the Eocene-Oligocene transition. Geology 36, 251-254 (2008).

66. Bralower, T. J. et al. Late Paleocene to Eocene paleoceanography of the equatorial Pacific Ocean: stable isotopes recorded at Ocean Drilling Program Site 865, Allison Guyot. Paleoceanography 10, 841-865 (1995).

67. Norris, R. D. et al. In Proc. IODP, 342 (Integrated Ocean Drilling Program, College Station, 2014).

68. Leutert, T. J. et al. Sensitivity of clumped isotope temperatures in fossil benthic and planktic foraminifera to diagenetic alteration. Geochim. Cosmochim. Acta 257, 354-372 (2019).

69. Coxall, H. K. Hantkeninid Planktonic Foraminifera And Eocene Palaeoceanographic Change. PhD thesis, University of Bristol (Bristol, 2000).

70. Gradstein, F. M. et al. The Geologic Time Scale, (Elsevier, Boston, 2012).

71. Pearson, P. \& Ezard, T. Evolution and speciation in the Eocene planktonic foraminifer Turborotalia. Paleobiology 40, 130-143 (2014).

72. Sexton, P. F., Wilson, P. A. \& Pearson, P. N. Microstructural and geochemical perspectives on planktic foraminiferal preservation: "Glassy" versus "Frosty". Geochem. Geophys. Geosys 7, Q12P19 (2006).

73. Edgar, K. M., Anagnostou, E., Pearson, P. N. \& Foster, G. L. Assessing the impact of diagenesis on $\delta^{11} \mathrm{~B}, \delta^{13} \mathrm{C}, \delta^{18} \mathrm{O}, \mathrm{Sr} / \mathrm{Ca}$ and $\mathrm{B} / \mathrm{Ca}$ values in fossil 
planktic foraminiferal calcite. Geochim. Cosmochim. Acta 166, 189-209 (2015).

74. Bohaty, S. M., Zachos, J. C., Florindo, F. \& Delaney, M. L. Coupled greenhouse warming and deep-sea acidification in the middle Eocene. Paleoceanography 24, PA2207 (2009).

75. Lauretano, V., Littler, K., Polling, M., Zachos, J. C. \& Lourens, L. J. Frequency, magnitude and character of hyperthermal events at the onset of the Early Eocene Climatic optimum. Clim 11, 1313-1324 (2015).

76. Westerhold, T., Röhl, U., Donner, B., McCarren, H. K. \& Zachos, J. C. A complete high-resolution Paleocene benthic stable isotope record for the central Pacific (ODP Site 1209). Paleoceanography 26, PA2216 (2011).

77. Littler, K., Röhl, U., Westerhold, T. \& Zachos, J. C. A high-resolution benthic stable-isotope record for the South Atlantic: implications for orbital-scale changes in late Paleocene-Early Eocene climate and carbon cycling. Earth Planet. Sci. Lett. 401, 18-30 (2014).

78. Lauretano, V., Hilgen, F. J., Zachos, J. C. \& Lourens, L. J. Astronomically tuned age model for the early Eocene carbon isotope events: a new highresolution $\delta^{13} \mathrm{C}$ benthic record of ODP Site 1263 between $\sim 49$ and $\sim 54 \mathrm{Ma}$. Newsl. Stratigr. 49, 383-400 (2016).

79. Stap, L. et al. High-resolution deep-sea carbon and oxygen isotope records of Eocene Thermal Maximum 2 and H2. Geology 38, 607-610 (2010).

80. Sexton, P. F. et al. Eocene global warming events driven by ventilation of oceanic dissolved organic carbon. Nature 471, 349-352 (2011).

81. McCarren, H., Thomas, E., Hasegawa, T., Röhl, U. \& Zachos, J. C. Depth dependency of the Paleocene-Eocene carbon isotope excursion: paired benthic and terrestrial biomarker records (Ocean Drilling Program Leg 208, Walvis Ridge). Geochem. Geophys. Geosys 9, Q10008 (2008).

82. Barker, S., Greaves, M. \& Elderfield, H. A study of cleaning procedures used for foraminiferal $\mathrm{Mg} / \mathrm{Ca}$ paleothermometry. Geochem. Geophys. Geosys 4, 8407 (2003).

83. Yu, J., Elderfield, H., Greaves, M. \& Day, J. Preferential dissolution of benthic foraminiferal calcite during laboratory reductive cleaning. Geochem. Geophys. Geosys 8, Q06016 (2007).

84. Foster, G. L. Seawater $\mathrm{pH}, \mathrm{pCO}_{2}$ and $\left[\mathrm{CO}_{3}{ }^{2-}\right]$ variations in the Caribbean Sea over the last $130 \mathrm{kyr}$ : A boron isotope and $\mathrm{B} / \mathrm{Ca}$ study of planktic foraminifera. Earth Plan. Sci. Lett. 271, 254-266 (2008).

85. Hönisch, B. et al. The geological record of ocean acidification. Science 335 , 1058-1063 (2012).

86. Ridgwell, A. \& Zeebe, R. E. The role of the global carbonate cycle in the regulation and evolution of the Earth system. Earth Plan. Sci. Lett. 234 299-315 (2005).

87. Liu, Z. et al. Global cooling during the Eocene-Oligocene climate Transition. Science 323, 1187-1190 (2009).

88. Zhang, Y. G., Pagani, M., Liu, Z., Bohaty, S. M. \& DeConto, R. A 40-millionyear history of atmospheric $\mathrm{CO}_{2}$. Philos. Trans. R. Soc. A. Math. Phys. Eng. Sci. 371, 20130096 (2013).

89. Pearson, P. N. \& Burgess, C. E. Foraminifer test preservation and diagenesis: Comparison of high latitude Eocene sites. In Special Publications, Vol. 303, 59-72 (The Geological Society, London, 2008).

90. Inglis, G. N. et al. Descent towards the Icehouse: Eocene sea surface cooling inferred from GDGT distributions. Paleoceanography 30, 1000-1020 (2015).

91. Tripati, A. K. et al. Tropical sea-surface temperature reconstruction for the early Paleogene using $\mathrm{Mg} / \mathrm{Ca}$ ratios of planktonic foraminifera. Paleoceanography 18, 1101 (2003).

92. Frieling, J. et al. Extreme warmth and heat-stressed plankton in the tropics during the Paleocene-Eocene Thermal Maximum. Sci. Adv. 3, e1600891 (2017).

93. Frieling, J. et al. Tropical Atlantic climate and ecosystem regime shifts during the Paleocene-Eocene Thermal Maximum. Clim 14, 39-55 (2018).

94. Martin, E. E. \& Scher, H. D. Preservation of seawater Sr and Nd isotopes in fossil fish teeth: bad news and good news. Earth Planet. Sci. Lett. 220, 25-39 (2004).
95. IPCC. Climate Change 2013: The Physical Science Basis. Contribution of Working Group I to the Fifth Assessment Report of the Intergovermental Panel on Climate Change. 1-1535 (2013).

96. Gettelman, A. et al. High climate sensitivity in the Community Earth System Model version 2 (CESM2). Geophys. Res. Lett. 46, 8329-8337 (2019).

\section{Acknowledgements}

Financial support was provided by NERC grants NE/I005595/1 and NE/P019048/1 to G.L.F., NE/P01903X/1 to D.J.L., NE/P019331/1 to P.F.S. and NE/I005870/1 to P.N.P., G.L.F., P.F.S. We acknowledge Sandra Kirtland Turner for making IODP 1409 material available to this study, Johanna Marquardt for assisting P.F.S. in IODP 1409 foraminiferal taxonomy, and Andy Milton for technical assistance. This research used samples and/or data provided by the International Ocean Discovery Program (IODP) and the Ocean Drilling Program (ODP). Open access funding provided by Projekt DEAL.

\section{Author contributions}

E.A. conducted the boron isotope and trace element analyses, calculations and drafted the manuscript. E.H.J., P.F.S. prepared foraminifer samples and provided taxonomic and age model expertise. P.N.P. led the taxonomy and foraminifera and age model selection. A.R. provided constrains on carbon cycling. T.L.B. with T.B.C. completed a subset of IODP 1409 boron isotope and elemental analyses. D.J.L. advised on climate sensitivity calculations, and D.J.L., R.D.P. and G.L.F. assisted on refining the discussion section. All co-authors contributed to the final text.

\section{Competing interests}

The authors declare no competing interests.

\section{Additional information}

Supplementary information is available for this paper at https://doi.org/10.1038/s41467020-17887-x.

Correspondence and requests for materials should be addressed to E.A.

Peer review information Nature Communications thanks Valeria Luciani, Cindy Shellito, and the other, anonymous, reviewer(s) for their contribution to the peer review of this work.

Reprints and permission information is available at http://www.nature.com/reprints

Publisher's note Springer Nature remains neutral with regard to jurisdictional claims in published maps and institutional affiliations.

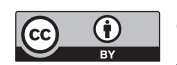

Open Access This article is licensed under a Creative Commons Attribution 4.0 International License, which permits use, sharing, adaptation, distribution and reproduction in any medium or format, as long as you give appropriate credit to the original author(s) and the source, provide a link to the Creative Commons license, and indicate if changes were made. The images or other third party material in this article are included in the article's Creative Commons license, unless indicated otherwise in a credit line to the material. If material is not included in the article's Creative Commons license and your intended use is not permitted by statutory regulation or exceeds the permitted use, you will need to obtain permission directly from the copyright holder. To view a copy of this license, visit http://creativecommons.org/ licenses/by/4.0/.

(C) The Author(s) 2020 